\title{
Shakespeare Production in the British Theatre: Too Much of a Good Thing?
}

\author{
Russell Jackson
}

\section{(QpenEdition \\ 1 Journals}

\section{Electronic version}

URL: http://journals.openedition.org/shakespeare/1213

DOI: 10.4000/shakespeare.1213

ISSN: 2271-6424

Publisher

Société Française Shakespeare

\section{Printed version}

Date of publication: 1 November 1990

Number of pages: $79-88$

\section{Electronic reference}

Russell Jackson, «Shakespeare Production in the British Theatre: Too Much of a Good Thing? », Actes des congrès de la Société française Shakespeare [Online], 8| 1990, Online since 01 January 2007,

connection on 06 May 2019. URL : http://journals.openedition.org/shakespeare/1213 ; DOI : 10.4000/ shakespeare. 1213 


\section{SHAKESPEARE \\ ET LA GUERRE}

Ouvrage publié avec le concours de la Commission

des Communautés Européennes 
Illustration de la couverture : DERRICKE'S Image of Ireland, 1586 


\section{Shakespeare Production in the British Theatre: Too Much of A Good Thing?}

It seems at the moment as though there may be an overabundance of Shakespearean production in Britain - almost amouting to a glut. At the time of writing, the English Shakespeare Company's season of history plays (from Richard II to Richard III) has just finished at the Old Vic, where Jonathan Miller's King Lear is previewing; the Royal Shakespeare Company's series of The Plantagenets (Henry VI, Edward IV, Richard III) is about to open at the Barbican and their new Stratford company is rehearsing; Derek Jacobi is appearing in Richard II and Richard III at the Phonix Theatre, where Sir Peter Hall's company is soon to present The Merchant of Venice with Dustin Hoffman as Shylock. Productions of The Tempest by Cheek by Jowl and Timon of Athens by Red Shift are touring; Hamlet has opened in the National Theatre's Olivier theatre; an Othello has just opened at the Greenwich theatre. In the provinces, repertory theatres regularly stage the Shakespeare plays favoured by examination boards - a policy which effectively restricts the range of Shakespeare to be seen in large theatres (if Pericles is done, it will be in a studio). Similar considerations govern the choice of plays for the Straford-upon-Avon main house repertoire.

Will it be possible to look back on the 1980s and identify a distinctive «Shakespearean» style of production? It seems that Shakespearean staging in the British theatre, responding to a variety of impulses and needs, is finding an extraordinary range of styles, from populist clarity to «deconstructive» innovation and from blandly 
«traditional» shows that could have been seen forty years ago to productions whose visual language competes for audiences with the big West-End and Broadway musicals or whose power to attract lies mainly in their «star» performers.

Viewed in a historical perspective, this variety appears unsurprising: Shakespeare has been proved time and again to be workable material for different theatrical projects and - perhaps most important - to be bankable at the box office. But this very dependability has been questioned. Is it the qualities of the plays themselves, or the predictable security of their values that attracts audiences? Is it true that Shakespeare's work has no particular claim on the paying public, unless it is part of a package that includes star performers or spectacular stagings? Some academic critics have questioned the desirability of the cultural practices of which Shakespeare is a focus, or for which the plays serve as a pretext. Cultural Materialism, the British marxist strain of «new historicism », which addresses itself to the politics of cultural transactions, has produced some searching critiques of the ideological function of the Royal Shakespeare Company (RSC). After years of being held at arm's length by more «traditional» academics because performance somehow contaminates the purity of the text, the RSC is now attacked by an influential group of radical academics on the grounds that it reinforces the ideologies of bourgeois individualism. At the same time, the subsidised theatres in Britain have to cope with the government's policies towards (rather than in support of) the arts, which demand that they should be subject to market forces, and should seek major financial support from industry and commerce. The RSC thus appears as a simultaneous tool and victim of Thatcherism.

But the RSC, even if it embodies an undesirable ideology in its very title and in the purposes for which it bears a Royal charter (to present the plays of one dramatist in his place of birth), is far from monolithic in its production style and methods. In recent years it has often 
seemed to be an umbrella organisation for the staging of productions by a diversity of directors. Its «flagship» productions on the main stages in Stratford and at the Barbican may seem to have a unity of style, dictated partly by the demands of the stages themselves and the response of designers and directors to the need to use them, but the company's most notable successes have been achieved in conditions that might be found in the «fringe» of British theatre. Such work as Deborah Warner's Titus Andronicus and King John has benefited from the RSC resources, not least in providing good casts from the larger Stratford and London companies, but the productions have used the thrust stage of the New Swan and the minimal facilities of The Other Place and the Pit, the Stratford and London studio theatres. These spaces need the financial support that is provided by the nightly filling (in a good season) of the adjacent main theatres where shows on a larger scale and plays from the "mainstream» make for safer boxoffice. It is no longer reasonable to speak of a RSC « house style» in the singular: a number of styles have been supported and absorbed by the company in recent seasons. Is this constructive pluralism or a case of the «establishment» engulfing its rivals?

The yearning among some sections of the public for a return to the «golden age» of a discernible Stratford «house style» has made it difficult to judge precisely what has been going on with The Plantagenets, in which the company seemed to be invoking the legendary success of the early 1960s, The Wars of the Roses. Adrian Noble's production recalls the earlier versions of the Henry VIRichard III sequence in finding a coherent production style for a trilogy of plays (grouped as Henry VI, Edward $I V$ and Richard III), but there are significant differences between the 1963 and 1988 RSC cycles, and, more significant for new theatregoers, the 1987-9 cycle of history plays staged by the English Shakespeare Company (ESC). The 1963 series was notable for signalling the absorption of lessons from Brecht into the British Shakespearean consciousness: sets and costumes were both emblematic 
and «real» and the characters seemed to inhabit a used, practical world rather than a picturesque one. Its most Brechtian moments were not dependent on superficial resemblances of staging, but on the attention given to negotiations. Hall and Barton achieved a version of the plays whose unity derived partly from the constant return to throne and council-table, the one trucked up and down the stage, the other raised and lowered from the floor. There was a strong sense of the way power was fought for among the magnates of the realm, not least in such scenes as the council-chamber sequence that was manufactured to introduce $E d w a r d I V$. The instrusion of the wider social world was restricted by the plays' paucity of «commons» scenes, but the Cade rebellion was treated unpatronisingly and the death of Suffolk was staged not as in the original (the pirates) but as a variation on the murder of Cinna the Poet: the fury of a mob, this time choosing the proper victim for its righteous but terrifying indignation. Most important was the effect of the other parts on the interpretation of Richard III, in which the protagonist became less glamorous and his victims more culpable than is usually the case. Ian Holm's Richard of Gloucester displeased several critics precisely on this account: where was the great melodramatic hero? Although the overall production style of the 1963 Wars of the Roses became the stuff of cliché - battles in swirling fog, drums and trumpets, a particular way with alarums and excursions - the impact of its cruel, uncompromising, un-pretty world for the history plays should not be underestimated.

In Adrian Noble's version, which uses a similar arrangement of the texts and gives the cycle in three threehour segments, the emphasis on the processes of power is not as strong. There are some fine performances. Ralph Fiennes is a Henry whose piety and pacific ambition are less downright weaknesses than strengths that are out of place in the world of the factions. Anton Lesser's Richard of Gloucester has a superficial charm that can fool crafty rivals and which modulates into a terrifying, glinting fanaticism in his own cause. Many of the stage-pictures are 
impressive, and the battles are varied pleasingly. But the overall effect is one of finely directed spectacle rather than the processes of power. Most of the grimness of the 1963 cycle seems to be absent, although as the plays progress the killings get more brutal, so that the death of Henry VI is accompanied by the raising of a backcloth that literally drips with stage-blood, and the final play culminates in a grotesque bloodletting when Richard's deformity is pierced by Richmond's spear. The overall effect is operatic in the best way: tableaux, ensembles, arias, spectacle. In more ways than one The Plantagenets seems designed to satisfy the British theatre goer's appetite for Wagnerian marathons. By contrast, Michael Bogdanov's series of history plays, for the ESC, rarely pauses to be picturesque, darts in and out of sometimes jokey use of anachronisms, and offers a series of tableaux in which power is bought, maintained and lost. Some of the effects are unsubtle, to say the least (direct parallels between football hooliganism and the army embarking for France in Henry $V$, and Henry dressed like an Action Man paratrooper doll for «Once more unto the breach...») but there is no chance of the audience reposing in the comfortable reflection that this is how things were. Bogdanov's staging has no place for mystifications of power or the comforting distance of «period» dress. His warlords use the modern media, and dress for the boardroom or the assault course. The productions, designed with brilliant economy to tour widely, manage to fill large stages with action and movement, but use relatively little by way of «special effects». By contrast, it has been reported that the RSC has had to spend $£ 50,000$ on refurbishing the Barbican stage to take The Plantagenets. Even when allowance is made for all the good reasons there might be for this expenditure, it remains as poor publicity for a company in need of increased funding.

The conclusion seems unavoidable that the real strengths of the RSC's work are to be found in its studios and its smaller thrust-stage theatre, and (it should be remembered) in the touring productions it sends out to 
«the. regions.»Some of the grander main-house shows have been successful, and The Plantegenets was greeted with some relief in the sympathetic press as a sign of the company back on form after some poor choices (notably the disaster of the musical Carrie on Broadway and some very confused planning ia the recent London seasons). But the odium of comparison will not go away. The ESC productions seem to offer large-scale Shakespeare in precisely that area - the history plays - that had been the RSC's special preserve.

The ESC and the other rival companies offer some challenges in style and working practice that suggest ways forward which the RSC is unable to take so long as its chief business is filling two large auditoria for long seasons. The RSC has also experienced some difficulty in attracting actors to work in Stratford, and then commit themselves to London, for sustained periods: the ideal "of a semipermanent ensemble, which powered the work of this company in the 1960s, has almost disappeared. (Although the current Stratford season, divided into two halves with separate companies, is an attempt to overcome the problem of location in Stratford and attract «star» actors back to the company). Both ESC and Renaissance Theatre Company are "actor-friendly» at a time when actors in the two national companies have been murmuring about the dominance of the directors in the artistic directorate and on the rehearsal-room floor.

Renaissance Theatre Company, founded by two actors to offer new ways of working on Shakespeare and other scripts, has achieved notable successes in a London run of Twelfth Night (subsequently televised) and a tour and London season of three Shakespeare plays, Much Ado about Nothing, Hamlet and As You Like It. The principal innovation of these three productions has been that of having famous actors to direct, bringing their experience to the productions but without appearing in them. Judi Dench, Derek Jacobi and Geraldine McEwan produced versions of the plays which used the same cast of fifteen actors, simple settings that could be used in 
theatres of varying sizes, and an emphasis on character and clarity and swiftness of speech and action. Though not lacking ideas, these productions were not dominated by «concept» - the sense of a director's or designer's overwhelming insight that has become something of a bugbear among actors. The principle of the company, as elucidated by its founders Kenneth Branagh and David Parfitt, has been to introduce actors into the director's position rather than to mount some kind of campaign against directors. As the company's text adviser I cannot claim an unbiassed view of the matter, but it seems to me from time spent in rehearsal of these and other Renaissance productions that the great advantage lies in the absence of barriers between cast and director: the actors are confident that they are in the hands of an experienced professional who knows their anxieties and sees how to use their talents. In some respects Renaissance is not «radical» - it does not take the texts apart to explore contradictions, it centres attention on story-telling and the exploration of character in a way that some find old-fashioned. But it has the virtues of these restrictions, and it delivers a kind of Shakepearean entertainment that box-office success suggests the audiences want. The vigour and straightforwardness of the productions - their bottom line, as it were - are complemented by some fine acting, a genuine ensemble and sensitive and enjoyable production.

The more radical alternatives, which also attract audiences, are well represented in the work of Cheek by Jowl. Their productions use small casts and minimal staging, but achieve a theatre of physical richness and inventiveness. This sometimes involves what must be admitted to be a «bending» of the words of the text: in Twelfth Night Toby sang, like a true drunk, all the verses of «I Did it My Way»; in The Tempest Caliban was recruited into the music-hall act of Stephano and Trinculo, and Naples had a Queen rather than a King. But the radicalism in Cheek by Jowl is almost invariably founded in a thorough reading and exploration of the text. In Declan Donellan's production of The Tempest they achieved the 
rare feat of holding attention with the Sebastian/Alonso sub-plot. Prospero careered through a series of disguises, from a modern theatre director to magus from the Age of Reason and (for the masque) a Victorian showman/undertaker. From the very beginning, in which the director as «master» of the ship instructed an actor to «speak to the mariners», theatrical, magical and temporal authority were in play. The politics and metatheatrics were explored, the psychology of each situation if not of Prospero's "character» were made clear. At the end the Queen of Naples was not at all sure that she approved of Prospero's having married off his (black) daughter to her son, and Prospero's power, always fragile, seemed to ebb from him as he revealed each sublety of the isle. The masque was a joyous parody of Offenbach, which the audience refused to take as seriously as Prospero hoped they would. This neatly sidestepped the usual problem of garish or feeble masques which audiences are suposed to accept as the high water-mark of a sage's tastes and abilities. Here was a theatrical show getting out of hand. Consequently «Our revels now are ended...» began in anger and exasperation, without a hint of serenity. The Queen of Naples ( $\ll$ Full fathom five thy mother lies...») looked very like the Prime Minister, one of whose pronouncements - «There is no such thing as society» - became a line in the productionnumber that Stephano and Trinculo taught to Caliban. In a year that had seen other major productions of the play (by Nicholas Hytner, Jonathan Miller and Peter Hall) this was the freshest and the most portable. Cheek by Jowl have a policy of playing a repertoire that mixes the rarelyseen (Calderón, Ostrovsky, Corneille) with the familiar and taking their work to as many venues as possible. Other companies work in a comparable way - Red Shift's Timon has recently attracted attention with its radical reworking of the text, its female Timon and its cultivation of a theatre of rich visual and aural sensations that arise from a meticulous use of the text. If the plays can be used with artistic power and grace to tell stories that do more than comfort the audience, then there is some hope. 
A historical overview of the 1980s, taken in a couple of decades'time, may well find no single «style of the 80s», but it will undoubtedly include the variety of organisations and diversity of aims current among the companies staging Shakespeare in Britain. It is intriguing (and worrying) to note that this diversity should be making itself felt at a time when the government is appealing to the free play of market forces as an argument against subsidy for the arts. Renaissance, for example, is financed entirely by private money, but its directors are anxious that their achievement should not be used to support arguments against subsidy. The «free play of market forces» may result in a demonstration of how little the public will take for production if it can get Shakespeare and star performances, and some recent productions have seemed to bear out this depressing fact. There is a widespread fear that the right to fail courageously will disappear from the commercialised theatre, and the right to lower standards of production and intellectual engagement will be asserted. There is also some justice in the argument that the Shakespeare «glut» simply drives good modern plays out of the theatre although quite what will drive audiences in to see them isn't clear. In the general dismantling of public services that is going on in Britain under the Tory government, the impoverishment of the subsidised theatres is the least spectacular: queues for his replacement operations affect the public more directly than the shortcomings of Shakespeare productions at the National or the RSC. But the ideals asserted in the founding of the National Theatre were as much «Victorian Values» as those espoused by the government: education, freedom from commercial constraints, art properly financed and widely available. The subsidised theatre arrived late in Britain and looks like departing early. What we can hope for is that the current enthusiasm for Shakespeare shows the public's eagerness to see variety and innovation in the live theatre, 
rather than a desire to fall back on glamourised old favourites.

Russell JACKSON

The Shakespeare Institute. Stratford-upon-Avon 